\title{
Osteoarticular changes and synovial biopsy findings in Wilson's disease
}

\author{
P. KAKLAMANIS AND M. SPENGOS
}

From the First Department of Internal Medicine and the Department of Neurology, University of Athens, School of Medicine, Greece

Wilson's disease (hepatolenticular degeneration) is an uncommon recessively inherited disease, in which various osteoarticular changes have been described (Finby and Bearn, 1958; Rosenoer and Michell, 1959; Walshe, 1962; Boudin, Pepin, and Hubault, 1964; Charbonnel, Vercelletto, LeMouroux, Besançon, and Fève, 1965; Mehta and Shinde, 1965; Cavallino and Grossman, 1968; Mindelzun, Elkin, Scheinberg, and Sternlieb, 1970; Feller and Schumacher, 1972).

Some patients with Wilson's disease present with arthralgia of the knees (Walshe, 1962) or have clinical signs or symptoms of osteoarthropathy (Feller and Schumacher, 1972).

The mechanism of most osteoarticular changes in Wilson's disease is unclear: copper overloading, renal tubular dysfunction, chronic spasticity and tremor, and liver failure have all been held responsible (Finby and Bearn, 1958; Feller and Schumacher, 1972).

Studies of synovial histology of only two patients with Wilson's disease have been published (Mindelzun and others, 1970; Feller and Schumacher, 1972). The synovial lesions present in haemochromatosis have, however, been described (Walker, Dymock, Ansell, Hamilton, and Williams, 1972), where mechanisms similar to those of Wilson's disease have been proposed (McCarty, Pepe, Solomon, and Cobb, 1970)

Our interest in the osteoarticular changes and synovial membrane lesions in Wilson's disease goes back to 1968 when we examined a patient with osteoarticular changes in most of the joints. Since then we have studied six more patients.

\section{Material and methods}

This paper, therefore, describes seven patients with Wilson's disease who were submitted to clinical and radiological examination of the locomotor system and to punch biopsy of the knee joints (with the Parker/Pearson needle) (Table). The synovial specimens were fixed in absolute alcohol as well as in 10 per cent. formalin, although the former is not necessary to preserve the crystals (Atkins, McIvor, Smith, Hamilton, and Williams, 1970). The synovium was examined by light microscopy, after staining with haematoxylin and eosin, as well as with the rubeanic acid stain for copper (Howell, 1959). The synovial findings were interpreted without knowledge of the clinical status or of the radiological changes.

In all but one patient the ceruloplasmin was lower than normal and all seven had Kayser-Fleischer rings. Calcium, phosphorus, alkaline phosphatase, and renal functioro were normal. In only one patient was the latex flocculation test positive. In this patient and in one other, liver function was also abnormal. Urinary aminoaciduria was increased in only one of the five patients in whom this was measured. Serum copper ranged between 30 and 102.

\section{Results}

\section{CLINICAL FINDINGS}

Three patients complained of arthralgia, one mainly in the hands (Case 3 ) and two in the knees (Cases 5 and 7). One patient (Case 7) presented with non-tender swelling of both knees for several months, four had retropatellar crepitus, and three had pain on flexion and extension of the knees, but none showed deformity. No serious discomfort was complained of by any patient.

A 22-year-old boy (Case 7) presented with effusions in both knees. Joint aspiration and synovial biopsy were performed, $5 \mathrm{ml}$. being aspirated from the right knee and 6.5 $\mathrm{ml}$. from the left. The synovial fluid was viscous, 300 and $250 \mathrm{cells} / \mathrm{mm}^{3}{ }^{3}$ were present respectively. Protein was 2.5 and $2.0 \mathrm{~g}$. per cent. respectively, no crystals were found, and the latex flocculation test was negative.

SYNOVIAL HISTOLOGY

In assessing the histological appearance, minor changes were ignored and only villus formation with intimal cell hyperplasia, fibrin deposition, vascularity, and chronic inflammatory cell infiltrate were considered as significant abnormalities. Microvilli and intimal cell hyperplasia were present in six patients, prominently in two. Many villi had also been 
Table Particulars of seven patients

\begin{tabular}{|c|c|c|c|c|c|c|c|c|}
\hline Case No. & & 1 & 2 & 3 & 4 & 5 & 6 & 7 \\
\hline Clinical observations & $\begin{array}{l}\text { Age (yrs) } \\
\text { Sex } \\
\text { Duration of disease } \\
\text { Arthralgia } \\
\text { Hydrarthrosis } \\
\text { Crepitus } \\
\text { Pain on motion } \\
\text { Eyes } \\
\text { CNS type }\end{array}$ & $\begin{array}{l}20 \\
M \\
1 \\
= \\
= \\
- \\
+ \\
+W S\end{array}$ & $\begin{array}{l}25 \\
\text { M } \\
2 \\
= \\
= \\
\overline{+} \\
+ \\
++W S\end{array}$ & $\begin{array}{l}17 \\
\mathbf{M} \\
8 \\
\mathbf{H} \\
\overline{\mathrm{K}} \\
\mathrm{K} \\
+ \\
+\mathrm{W}\end{array}$ & $\begin{array}{l}33 \\
\mathbf{M} \\
8 \\
- \\
\bar{K} \\
\overline{+} \\
++W S\end{array}$ & $\begin{array}{l}25 \\
F \\
13 \\
K \\
- \\
K \\
K \\
+ \\
++W\end{array}$ & $\begin{array}{l}18 \\
\mathbf{M} \\
15 \\
- \\
- \\
- \\
+ \\
++W\end{array}$ & $\begin{array}{l}22 \\
\mathbf{M} \\
19 \\
\mathbf{K} \\
\mathbf{K} \\
\mathbf{K} \\
\mathbf{K} \\
+ \\
++\mathrm{W}\end{array}$ \\
\hline Results of laboratory tests & $\begin{array}{l}\text { Serum latex flocculation test } \\
\text { Liver } \\
\text { Kidneys } \\
\text { Urinary aminoacids } \\
\text { Serum copper ( } \mu \text { g. per cent.) }\end{array}$ & $\begin{array}{l}\overline{-} \\
\bar{n} \\
\text { n.d. }\end{array}$ & $\begin{array}{l}- \\
\bar{N} \\
65\end{array}$ & $\begin{array}{l}- \\
\overline{-} \\
\bar{N} \\
70\end{array}$ & $\begin{array}{l}- \\
\overline{-} \\
\bar{I} \\
45\end{array}$ & $\begin{array}{l}- \\
\overline{-} \\
\bar{N} \\
50\end{array}$ & $\begin{array}{l}\bar{t} \\
\bar{N} \\
102\end{array}$ & $\begin{array}{l}+ \\
++ \\
\bar{n} . d \\
30\end{array}$ \\
\hline Synovial histology & $\begin{array}{l}\text { Villi+ intimal hyperplasia } \\
\text { Fibrin deposition } \\
\text { Vascular changes } \\
\text { Chronic inflammatory cell } \\
\text { infiltrate }\end{array}$ & $\begin{array}{l}++ \\
- \\
+\end{array}$ & $\begin{array}{l}+ \\
- \\
+\end{array}$ & $\begin{array}{l}+ \\
+ \\
+\end{array}$ & $\bar{z}$ & $\begin{array}{l}+ \\
+ \\
+\end{array}$ & $\begin{array}{l}+ \\
+ \\
+\end{array}$ & $\begin{array}{l}++ \\
++ \\
++\end{array}$ \\
\hline Radiology & $\begin{array}{l}\text { Osteoporosis } \\
\text { Bone fragmentation } \\
\text { Osteoarthritis } \\
\text { Chondromalacia patellae } \\
\text { Subchondral bone fragments } \\
\text { +subcortical sclerosis } \\
\text { Fractures }\end{array}$ & $\begin{array}{l}+ \\
+ \\
++ \\
+ \\
++ \\
+\end{array}$ & $\begin{array}{l}\bar{z} \\
\dot{+} \\
\overline{-} \\
+\end{array}$ & $\begin{array}{l} \pm \\
- \\
- \\
+ \\
+\end{array}$ & $\begin{array}{l}- \\
++ \\
+ \\
+ \\
+\end{array}$ & $\begin{array}{l}- \\
++ \\
+ \\
+++ \\
+++ \\
+\end{array}$ & $\begin{array}{l}\bar{z} \\
\bar{z} \\
\bar{z}\end{array}$ & $\begin{array}{l}+ \\
+ \\
++ \\
+ \\
++\end{array}$ \\
\hline
\end{tabular}

\begin{tabular}{|c|c|c|c|}
\hline $\begin{array}{l}\mathbf{H}=\mathbf{H a n d s} \\
\mathbf{K}=\mathbf{K n e e s}\end{array}$ & $\begin{array}{l}t=\text { Present } \\
-=\text { Absent }\end{array}$ & $\begin{array}{l}\text { WS }=\text { Westphal-Strumpell } \\
\mathbf{W}=\text { Wilson }\end{array}$ & $\begin{aligned} \mathbf{N} & =\text { Normal } \\
\text { n.d. } & =\text { Not done }\end{aligned}$ \\
\hline
\end{tabular}

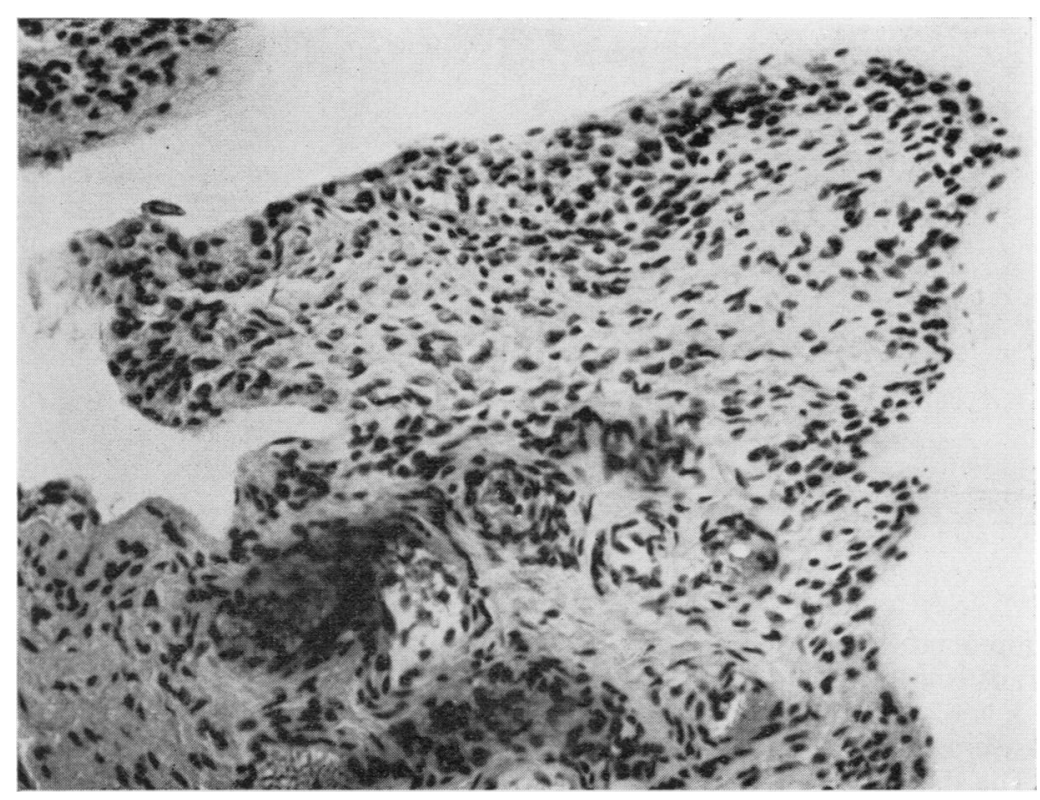

FIG. 1 Case 1. Villus formation and slight chronic inflammatory cell infiltrate. Haematoxylin and eosin. $\times 160$

formed in these two patients (Figs 1 and 2). Fibrin deposit was present in only one patient and chronic inflammatory cell infiltrate in six. Four patients had vascular lesions (Fig. 3).
No copper deposition was demonstrated in any of the seven specimens stained with rubeanic acid, nor were crystals of calcium pyrophosphate seen in the synovial membrane. 


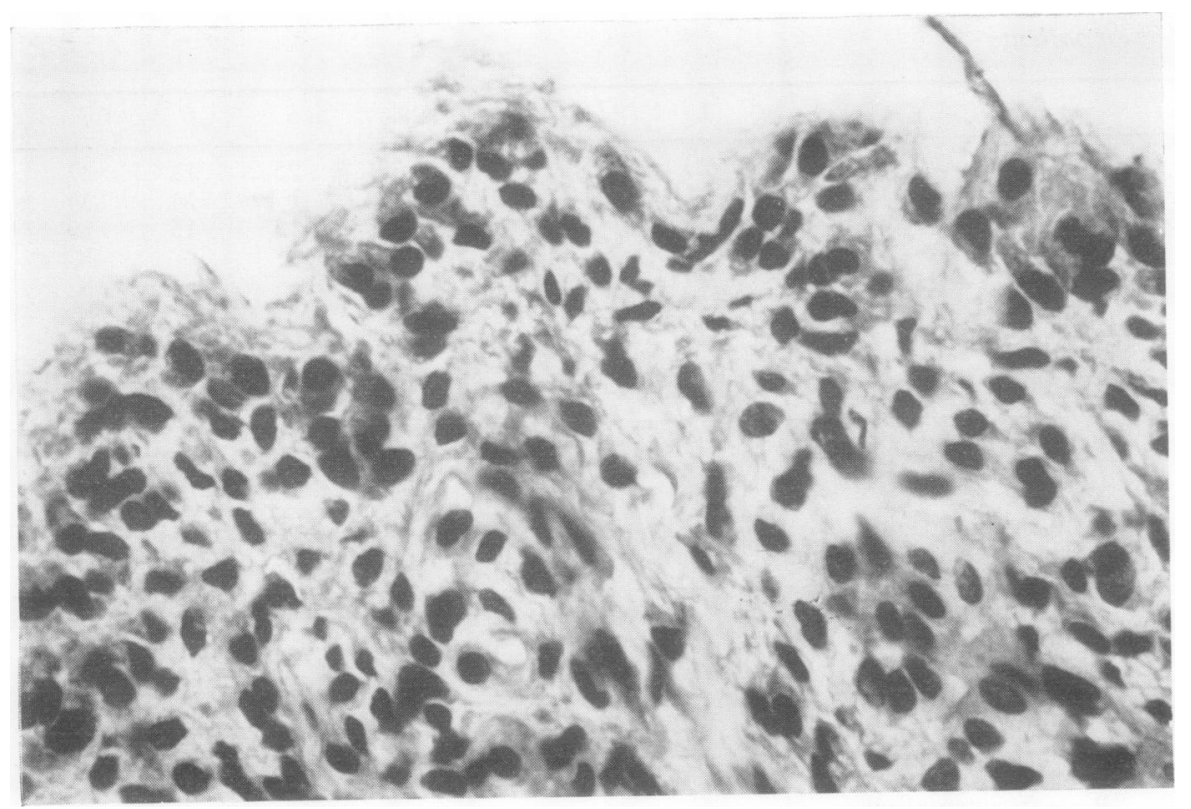

FIG. 2 Case 7.

Microvillusinhigher-

power view, showing hyperplasia of the intimal cell and chronic cell infiltrate. Haematoxylin and eosin. $\times 640$

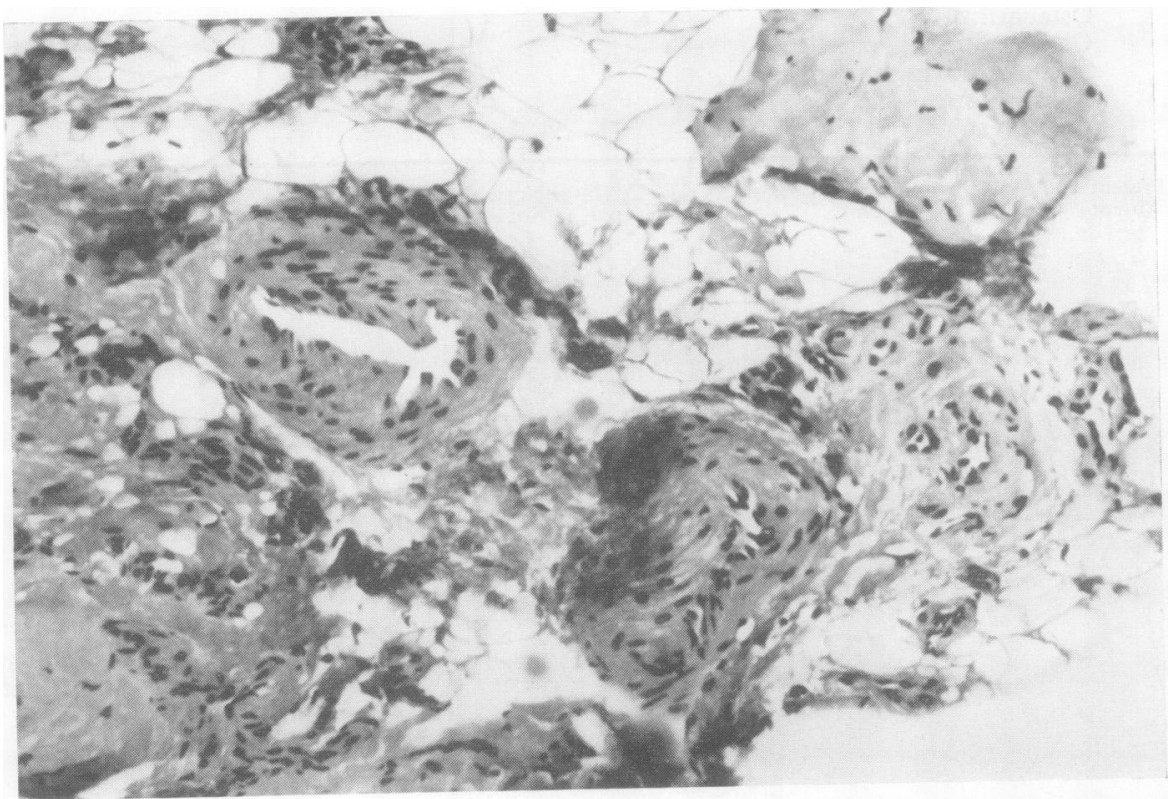

FIG. 3 Case 7.

Vascular changes in the stroma. Haematoxylin and eosin. $\times 160$

\section{RADIOLOGY}

Two (Cases 5 and 7) of three symptomatic patients showed significant $x$-ray findings: osteoarthritis and chondromalacia patellae in Case 5 , and subchondral bone irregularity with subcortical sclerosis and osteochondritis dissecans in Case 7. The third (Case 3) showed only minor changes. Two other asymptomatic patients (Cases 1 and 2) also had abnormal radiographs. Mild demineralization was found in only three patients. Bone fragmentation was seen in the knees (4), wrists (3) (Fig. 4), elbow, 5th right digit, right hip, right shoulder, right acromioclavicular joint, and symphysis pubis (1 each). Four patients showed premature osteoarthritis in one or more $\omega$ joints (knees (1), wrists (1), hips (2) (Fig. 5), elbows (1), metacarpophalangeal joints (1), ankles (1), and cervical spine (1)). Chondromalacia patellae was seen in two patients (Fig. 6). Subchondral bone irregularity? was found in six patients (localized in the knees (6), $\frac{0}{0}$ wrists (3), metacarpophalangeal joints (3), elbows (2), metatarsophalangeal joints (2), head of the right $\frac{?}{\circ}$ humerus (1), right trochanter (1), and right foot (1)). Subchondral bone irregularity, erosive changes, 
i

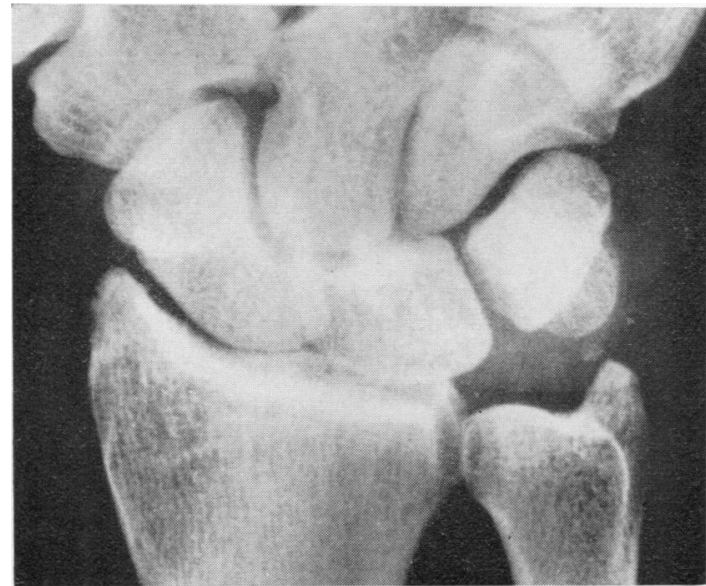

FIG. 4 Case 2. Right wrist, showing bony ossicle adjacent to the ulnar styloid process, subchondral bone irregularity, and sclerosis in a 25-year-old man with Wilson's disease for 2 years

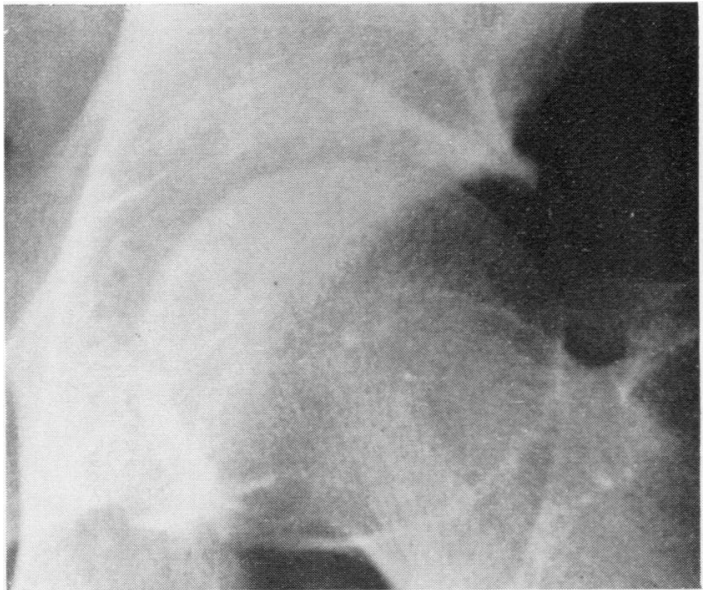

FIG. 5 Case 7. Degenerative changes of the left hip with hypertrophic spurring of the acetabulum in a 22-year-old man with Wilson's disease for 19 years

and subcortical sclerosis were strikingly evident in three patients (Fig. 7).

Pathological fractures were seen in two, one in the left radius (Fig. 8, overleaf) and the other in the left humeral condyle.

Osteochondritis dissecans was found in the knees of one patient. Subchondral cysts were rarely found. Milkman pseudofractures, chondrocalcinosis, and periosteal proliferation were not seen.

\section{Discussion}

The histological appearance of the synovial membrane of these patients resembles in some ways that

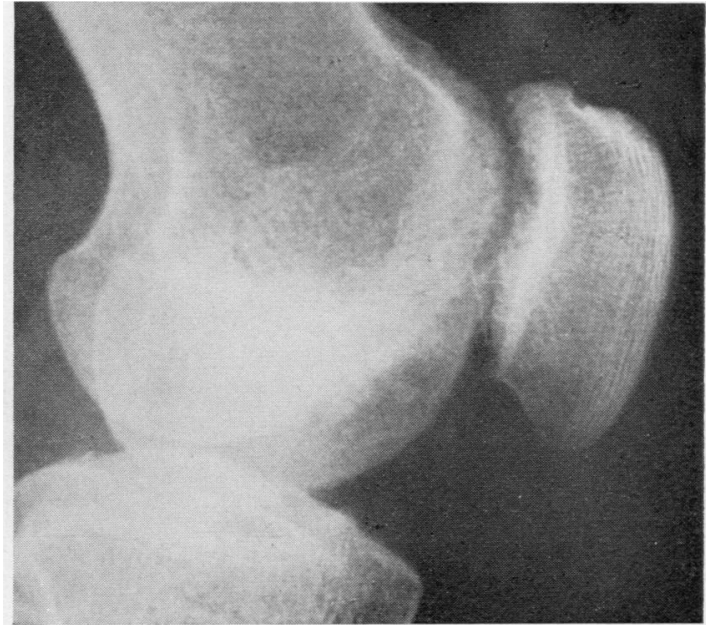

FIG. 6 Case 5. Chrondromalacia patellae of the right knee with subchondral irregularity of the femoral condyle in a 25-year-old woman with Wilson's disease for 13 years

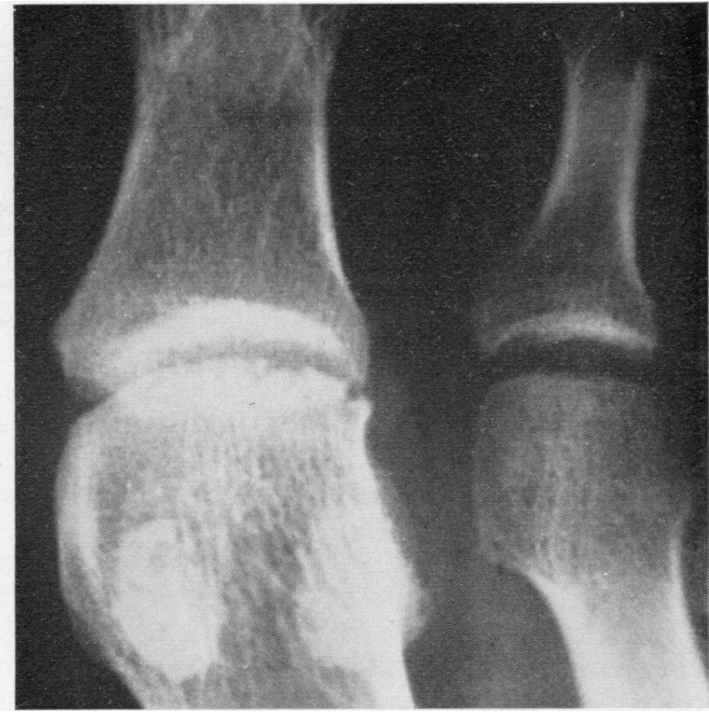

FIG. 7 Case 5. Subchondral irregularity and subcortical sclerosis and erosions of the head of the first metatarsal in a 25-year-old woman with Wilson's disease for 13 years

found in haemochromatosis (Walker and others, 1972). Villus formation with intimal cell hyperplasia, vasculitis, and chronic inflammatory cell infiltrate were the most prominent and most frequent findings. Chronic inflammatory cell infiltrate and microvillus formation were found mainly in cases with longstanding disease. All patients with symptoms and some without showed intimal cell hyperplasia and chronic inflammatory cell infiltrate. 


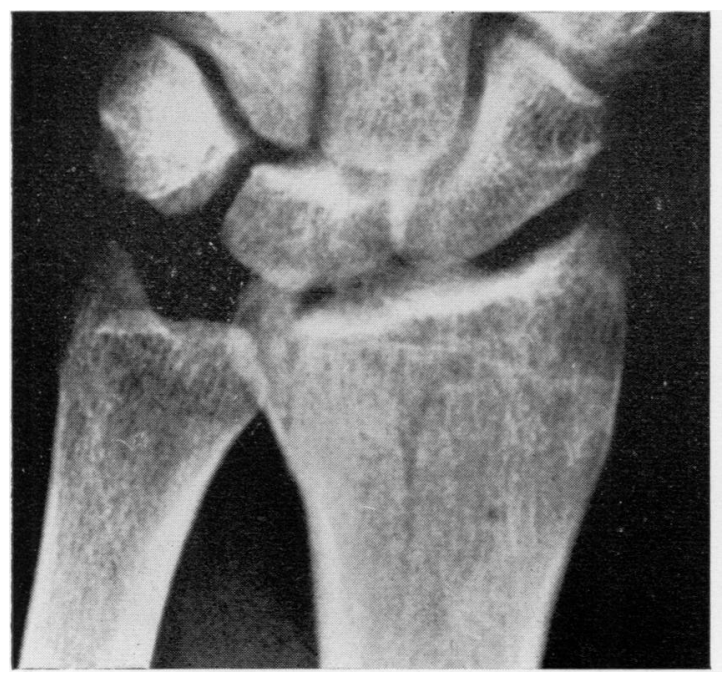

FIG. 8 Case 1. Fractures of the right radius in a 20-yearold man with Wilson's disease for 1 year

No patient had been previously treated with penicillamine, so that this treatment could not be responsible. There is thus no explanation at the moment for these findings, but the possibility of a chronic irritative effect from copper overloading cannot be excluded.

The radiological appearances have been described in the past and various mechanisms have been proposed (Finby and Bearn, 1958; Feller and Schumacher, 1972). Bone fragments at the joint margins of five patients may represent accessory skeletal elements or calcifications of bursae or tendons (Köhler, 1968), although the relationship with Wilson's disease cannot be excluded (Feller and Schumacher, 1972). Some may also represent fragments of bone detached from the near area. Pathological compression fractures of the kind found in two patients have also been described before. Patients with Wilson's disease have a tendency to sustain fractures (André, 1946; Finby and Bearn, 1958; Slovis, Dubois, Rodgerson, and Silverman, 1971). Premature osteoarthritic lesions were localized mainly in the knees, ankles, and elbows in patients under 25 years old, and trauma or tremors can therefore scarcely have been responsible (Finby and Bearn, 1958).

Chondromalacia patellae, which has been described in association with Wilson's disease by Feller and Schumacher (1972), was present in both knees in two of our patients. Subchondral bone irregularities were observed in the knees, wrists, elbows, metacarpophalangeal joints, and metatarsophalangeal joints, where some subchondral cysts, erosions, and sclerosis were also seen. Osteochondritis dissecans, detected in the knees of one of our patients, has also been described previously (Rosenoer and Michell, 1959; Mindelzun and others, 1970; Walshe, 1962).

Chondrocalcinosis of the knee joints was not found in our patients, but its presence has been reported and suggests a similarity with the arthropathy of other metabolic diseases (Schumacher, 1964; Boudin and others, 1964; Dymock, Hamilton, Laws, and Williams, 1970; Bywaters, Dorling, and Sutor, 1970). Rickets or osteomalacia have been described as an unusual finding in Wilson's disease (Finby and Bearn, 1958; Mehta and Shinde, 1965; Cavallino and Grossman, 1968) to which nutritional factors may have contributed (Feller and Schumacher, 1972)

There was no relationship between synovial membrane findings and radiographic changes. However, the small number of our patients included in the study and the difficulty of interpreting synovial specimens histologically (Sherman, 1951; Cruickshank, 1952; Wilkinson and Jones, 1963) make it impossible to draw general conclusions.

If copper overloading is the only cause of the osteoarthritic changes in Wilson's disease, the disagreement between the $x$-ray findings and the histological changes cannot be resolved. Walker and others (1972) could find no correlation between the synovial histology and the radiological evidence of arthro-? pathy in patients with haemochromatosis. Further studies are clearly necessary to elucidate the osteoarticular findings in Wilson's disease.

\section{Summary}

The clinical picture, histological changes in the synovial membrane, and radiological findings in seven patients with Wilson's disease are described. Five patients developed symptoms in the joints or were found to have clinical signs with no clear relationship to age or duration of disease. Microvillus formation, hyperplasia of the intimal cells, vascular changes, and chronic inflammatory cell infiltrate were found in six patients. No deposit of copper was detected in the synovial membrane. Bone fragmentation, subchondral bone irregularity, osteoarthritic changes, subcortical sclerosis, chondromalacia patellae, fractures, and osteochondritis dissecans were found. The pathogenesis of the synovial membrane lesions and of the radiological findings remains obscure.

The authors are indebted to Dr. P. Ioannides (Biochemist, Athens) and Mr. John Watson (Canadian Red Cross, Memorial Hospital, Taplow, Berks., England) for the rubeanic acid stain. 


\section{References}

ANDRÉ, M. J. (1946) Rev. belge Sci. méd., 17, 185 (Des signes biologiques et des caractères cliniques de la cirrhose Wilsonienne)

Atkins, C. J., McIvor, J., Smith, P. M., Hamilton, E. B. D., AND Williams, R. (1970) Quart. J. Med., 39, 71 (Chondrocalcinosis and arthropathy. Studies in haemochromatosis and in idiopathic chondrocalcinosis)

Boudin, G., Pepin, B., And Hubault, A. (1964) Rev. Rhum., 31, 594 (Les arthropathies de la maladie de Wilson)

Bywaters, E. G. L., Dorling, J., AND Sutor, J. (1970) Ann. rheum. Dis., 29, 563 (Ochronotic densification)

Cavallino, R., and Grossman, H. (1968) Radiology, 90, 493 (Wilson's disease presenting with rickets)

Charbonnel, A., Vercelletto, P., Mouroux, P. Le, Besançon, G., ANd Fève, J. R. (1965) J. Méd. Nantes, 5, 121 (Les arthropathies de la maladie de Wilson)

Cruickshank, B. (1952) Ann. rheum. Dis., 11, 137 (Interpretation of multiple biopsies of synovial tissue in rheumatic diseases)

Dymock, I. W., Hamilton, E. B. D., Laws, J. W., AND Williams, R. (1970) Ibid., 29, 469 (Arthropathy of haemochromatosis. Clinical and radiological analysis of 63 patients with iron overload)

Feller, E. R., AND SCHUMACHER, H. R. (1972) Arthr. and Rheum., 15, 259 (Osteoarticular changes in Wilson's disease)

FinBY, N., AND BeARN, A. G. (1958) Amer. J. Roentgenol., 79, 603 (Roentgenographic abnormalities of the skeletal system in Wilson's disease (Hepatolenticular degeneration))

Howell, J. S. (1959) J. Path. Bact., 77, 473 (Histochemical demonstration of copper in copper-fed rats and in hepatolenticular degeneration)

KöHLER, A. (1968) 'Borderlands of the Normal and Early Pathologic in Skeletal Roentgenology', 3rd. American ed., trans. S.P. Wilk, based on 11 th German ed., ed. E. A. Zimmer. Grune and Stratton, New York

McCarty, D. J., PePe, P. F., Solomon, S. D., AND CobB, J. (1970) Arthr. and Rheum., 13, 336 (Inhibition of human erythrocyte pyrophosphatase activity by calcium, cupric and ferrous ions) (Abstract)

MeHTA, R. S., AND SHINDE, V. A. (1965) Neurology (India), 13, 67 (Wilson's disease with rickets)

Mindelzun, R., Elkin, M., Scheinberg, I. H., AND Sternlieb, I. (1970) Radiology, 94, 127 (Skeletal changes in Wilson's disease)

RosenOeR, V. M., AND Michell, R. C. (1959) Brit.J. Radiol., 32, 805 (Skeletal changes in Wilson's diseaseHepatolenticular degeneration)

SCHUMACHER, H. R. (1964) Arthr. and Rheum., 7, 41 (Hemochromatosis and arthritis)

SHERMAN, M. S. (1951) Bull. Hosp. Jt Dis., 12, 110 (The non-specificity of synovial reactions)

Slovis, T. L., Dubois, R. S., Rodgerson, D. O., AND Silverman, A. (1971) J. Pediat., 78, 578 (The various manifestations of Wilson's disease)

Walker, R. J., Dymock, I. W., Ansell, I. D., Hamilton, E. B. D., and Williams, R. (1972) Ann. rheum. Dis., 31, 98 (Synovial biopsy in haemochromatosis arthropathy. Histological findings and iron deposition in relation to total body iron overload)

WaLShe, J. M. (1962) Arch. Dis. Childh., 37, 253 (Wilson's disease, the presenting symptoms)

Wilkinson, M., AND Jones, B. S. (1963) Ann. rheum. Dis., 22, 100 (Evaluation of needle biopsy of synovial membrane) 